\title{
Conus hughmorrisoni, a new species of cone snail from New Ireland, Papua New Guinea (Gastropoda: Conidae)
}

\author{
Felix LORENZ ${ }^{1} \&$ Nicolas PUILLANDRE ${ }^{2}$ \\ ${ }^{1}$ Fr.-Ebert-Str 12, 35418 Buseck, Germany. \\ Email: felix@cowries.info \\ ${ }^{2}$ Institut de Systématique, Évolution, Biodiversité ISYEB - UMR 7205 - \\ CNRS, MNHN, UPMC, EPHE, Muséum national d'Histoire naturelle, Sorbonne Universités, \\ 57 rue Cuvier, CP26, F-75005, Paris, France. \\ Email: puillandre@mnhn.fr (corresponding author); tel: +33140793173. \\ ${ }^{1}$ urn:Isid:zoobank.org:author:44070096-9354-4DF0-88ED-0D5D6CD2AB81 \\ ${ }^{2}$ urn:1sid:zoobank.org:author:00565F2A-C170-48A1-AAD9-16559C536E4F
}

\begin{abstract}
Based on newly collected material from the Kavieng Lagoon Biodiversity Survey, we describe a new species of cone snail, Conus hughmorrisoni sp. nov., from the vicinity of Kavieng, New Ireland, Papua New Guinea. It closely resembles the New Caledonian C. exiguus and the Philippine C. hanshassi, but differs from these species by having more numerous shoulder tubercles, by the shell's sculpturing and details of the color pattern. We also sequenced a fragment of the mitochondrial COI gene of five specimens collected alive. All possessed very similar sequences (genetic distances $<0.3 \%$ ), different from all the COI sequences of cone snails available in GenBank (genetic distances $>10 \%$ ).
\end{abstract}

Keywords. COI mitochondrial gene, Conidae, Conus hughmorrisoni sp. nov., new species, New Ireland.

Lorenz F. \& Puillandre N. 2015. Conus hughmorrisoni, a new species of cone snail from New Ireland, Papua New Guinea (Gastropoda: Conidae). European Journal of Taxonomy 129: 1-15. http://dx.doi.org/10.5852/ejt.2015.129

\section{Introduction}

We are now standing on over 250 years of species descriptions, and apart from vertebrates and butterflies, few animal groups have attracted as much attention from taxonomists as cone snails (Dance 1986). They have always been prized by shell collectors and studied by amateur conchologists as well as malacologists for their remarkable forms, colors, and biogeographical and ecological patterns. They are present in all the tropical regions, sometimes abundant (and thus easy to collect) in shallow waters, and can be found up to $700 \mathrm{~m}$ deep. Cone snails, as the other members of the superfamily Conoidea, are characterized by a venom apparatus. The venom, comprising up to 200 different toxins ("conotoxins"), specific to each species of cone snails (Dutertre et al. 2013; Violette et al. 2012), is injected in the prey (worms, molluscs or fish) by a highly modified harpoon-shaped radular tooth. The relatively recent discovery of conotoxins and their therapeutical applications is also fueling the enthusiasm of the scientific community for cone snails, and the discovery of a new species is always a warranty to discover new toxins. 
Given its relatively recent origin - 55 MY (Duda \& Kohn 2005) - cone snails (i.e., Conidae) is one of the most diverse group of marine invertebrates, with currently 820 species considered as valid (WoRMS, 1 Oct. 2014). New species are described regularly, and among the taxa Bacher analysed (Bacher 2012), the number of species described per taxonomist has declined since about 1900 in all but one taxon: the cone snails. In 2014 alone, 45 new species were described (WoRMS, 1 Oct. 2014). In the last 30 years, an average of 11.5 new species have been described each year, totaling nearly $42 \%$ of all valid species since 1758.

However, if new species descriptions are published often and regularly, they generally correspond to a form that was known for decades by malacologists but never described as a new species; discovering an unknown form of cone snail in shallow water is thus relatively uncommon and remarkable. In this article we describe a new species of cone snail, Conus (Splinoconus) hughmorrisoni sp. nov. (following the classification of Puillandre et al. 2015), discovered during the Kavieng Lagoon Biodiversity Survey ("KAVIENG 2014") in Papua New Guinea (June 2014), during which numerous new species have been discovered, some of them described already (Ahyong 2014). On the third day of diving, a little Conus Linnaeus, 1758 crawling across a piece of coral at $11 \mathrm{~m}$ was caught, and during the following weeks, several further specimens were collected. Additional shells were found in the vicinity of where the species was first discovered, confirming the consistency of the shell characteristics, different from all the known species of cone snails. The sequencing of a fragment of the mitochondrial COI gene also confirmed that the new species is different from the species for which a COI gene is available in public databases.

\section{Material and methods}

Part of the material was collected during the Kavieng Lagoon Biodiversity Survey in Papua New Guinea (June 2014; Principal Investigators: Philippe Bouchet, Jeff Kinch), as part of the Our Planet Reviewed expeditions. Some additional specimens come from private collections. Specimens collected alive were microwaved (Galindo et al. 2014) to remove the body from the shell and a piece of foot tissue was preserved in ethanol. A buccal complex was dissected to isolate the radular sac, which was then treated with a solution of commercially available bleach until soft tissues were completely dissolved. The radula was then rinsed in several shifts of distilled water, air dried and mounted for further SEM examination. DNA was extracted using the Epmotion 5075 robot (Eppendorf), following the manufacturers' recommendations. A fragment of the cytochrome oxidase subunit I (COI) was amplified using universal primers LCO1490/HCO2198 (Folmer et al. 1994). PCR reactions were performed in $25 \mu 1$, containing $3 \mathrm{ng}$ of DNA, $1 \mathrm{X}$ reaction buffer, $2.5 \mathrm{mM} \mathrm{MgCl} 2,0.26 \mathrm{mM}$ dNTP, $0.3 \mathrm{mM}$ of each primer, $5 \%$ DMSO, and 1.5 units of Qbiogene Q-Bio Taq. Amplification consisted of an initial denaturation step at $94^{\circ} \mathrm{C}$ for $4 \mathrm{~min}$, followed by 35 cycles of denaturation at $94^{\circ} \mathrm{C}$ for $30 \mathrm{~s}$, annealing at $50^{\circ} \mathrm{C}$ for COI, followed by extension at $72^{\circ} \mathrm{C}$ for $1 \mathrm{~min}$. The final extension was at $72^{\circ} \mathrm{C}$ for $5 \mathrm{~min}$. PCR products were purified and sequenced by the Eurofins sequencing facility. Specimens are registered in the MNHN collections and sequences were deposited in BOLD (Barcode of Life Datasystem) and GenBank (Table 1).

COI sequences of cone snails were downloaded from GenBank and aligned with the newly produced COI sequences using using Muscle 3.8.31 (Edgar 2004). Given the size of the dataset (more than 1700 sequences), a first quick analysis was performed to reduce the dataset. A neighbor-joining (NJ) analysis with Kimura-2-parameters (K2P) genetic distances was performed using MEGA 5 (Tamura et al. 2011) to roughly identify the group in which the new species clustered. Closely related sequences in the NJ tree (i.e., corresponding to the species belonging to the Floraconus, Leporiconus and Splinoconus clades, as defined in Puillandre et al. 2014), together with sequences of more distant species (used as outgroups), were then retained in the final dataset. Bathytoma neocaledonica Puillandre, Sysoev, Olivera, Couloux \& Bouchet, 2010 (Conoidea, Borsoniidae), was used as distant outgroup to root the tree. The final dataset was analysed using a Bayesian approach as implemented in MrBayes 3.2 (Huelsenbeck et al. 2001), with two runs each consisting of three Markov chains of 10000000 generations, each with a 
LORENZ F. \& PUILLANDRE N., Conus hughmorrisoni, a new species of cone snail

Table 1. List of specimens used in the final dataset for phylogenetic analyses.

\begin{tabular}{|c|c|c|c|c|}
\hline Species & MNHN voucher number & Status & BOLD ID & $\begin{array}{c}\text { GenBank } \\
\text { Accession Number } \\
\end{array}$ \\
\hline Conus hughmorrisoni sp. nov. & MNHN IM-2013-53462 & Holotype & CONO1794-15 & KR070759 \\
\hline Conus hughmorrisoni sp. nov. & MNHN IM-2013-53463 & Paratype 2 & CONO1795-15 & KR070758 \\
\hline Conus hughmorrisoni sp. nov. & MNHN IM-2013-53464 & Paratype 3 & CONO1796-15 & KR070757 \\
\hline Conus hughmorrisoni sp. nov. & MNHN IM-2013-53771 & Paratype 1 & CONO1793-15 & KR070760 \\
\hline Conus hughmorrisoni sp. nov. & MNHN IM-2013-53772 & Paratype 4 & CONO1792-15 & KR070761 \\
\hline \multicolumn{4}{|c|}{ Conus balteatus G. B. Sowerby I, 1833} & KJ550134 \\
\hline \multicolumn{4}{|l|}{ Conus biliosus (Röding, 1798) } & KJ549870 \\
\hline \multicolumn{4}{|l|}{ Conus boeticus Reeve, 1844} & KJ550139 \\
\hline \multicolumn{4}{|l|}{ Conus capitanellus Fulton, 1938} & KJ549891 \\
\hline \multicolumn{4}{|l|}{ Conus coffeae Gmelin, 1791} & KJ550178 \\
\hline \multicolumn{4}{|l|}{ Conus corallinus Kiener, 1847} & KJ550163 \\
\hline \multicolumn{4}{|c|}{ Conus distans Hwass in Bruguière, 1792} & KJ550205 \\
\hline \multicolumn{4}{|c|}{ Conus fumigatus Hwass in Bruguière, 1792} & KJ550268 \\
\hline \multicolumn{4}{|c|}{ Conus glans Hwass in Bruguière, 1792} & KJ549918 \\
\hline \multicolumn{4}{|c|}{ Conus granum Röckel \& Fischöder, 1985} & KJ549922 \\
\hline \multicolumn{4}{|c|}{ Conus hamamotoi Yoshiba \& Koyama, 1984} & KJ550283 \\
\hline \multicolumn{4}{|c|}{ Conus lenavati da Motta \& Röckel, 1982} & KJ550324 \\
\hline \multicolumn{4}{|c|}{ Conus luteus G. B. Sowerby I, 1833} & KJ549942 \\
\hline \multicolumn{4}{|c|}{ Conus mozambicus Hwass in Bruguière, 1792} & KJ550075 \\
\hline \multicolumn{4}{|c|}{ Conus queenslandis da Motta, 1984} & KJ550432 \\
\hline \multicolumn{4}{|c|}{ Conus roseorapum G. Raybaudi \& da Motta, 1990} & KJ550544 \\
\hline \multicolumn{4}{|l|}{ Conus sazanka Shikama, 1970} & KJ550444 \\
\hline \multicolumn{4}{|c|}{ Conus shikamai Coomans, Moolenbeek \& Wils, 1985} & KJ549989 \\
\hline \multicolumn{4}{|l|}{ Conus sp. } & KJ550327 \\
\hline \multicolumn{4}{|c|}{ Conus tenuistriatus G. B. Sowerby II, 1858} & KJ550476 \\
\hline \multicolumn{4}{|c|}{ Conus tinianus Hwass in Bruguière, 1792} & KJ550002 \\
\hline \multicolumn{4}{|l|}{ Conus tribblei Walls, 1977} & KJ550510 \\
\hline \multicolumn{4}{|l|}{ Conus viola Cernohorsky, 1977} & KJ550010 \\
\hline \multicolumn{4}{|l|}{ Conus voluminalis Reeve, 1843} & KJ550525 \\
\hline \multicolumn{4}{|c|}{ Conasprella pagoda (Kiener, 1847) } & EU015729 \\
\hline \multicolumn{4}{|c|}{ Californiconus californicus (Reeve, 1844) } & KJ549878 \\
\hline \multicolumn{4}{|c|}{ Profundiconus vaubani (Röckel \& Moolenbeek, 1995) } & KJ550518 \\
\hline \multicolumn{4}{|c|}{ Bathytoma neocaledonica Puillandre, Sysoev, Olivera, Couloux \& Bouchet, 2010} & EU015653 \\
\hline
\end{tabular}

sampling frequency of one tree each 500 generations. Each codon position of the COI gene was treated as an unlinked partition, each following a GTR model, with a gamma-distributed rate variation across sites approximated in four discrete categories and a proportion of invariable sites. Convergence of each analysis was evaluated using Tracer 1.4.1 (Rambaut \& Drummond 2007) and analyses were terminated when ESS values were all greater than 200. A consensus tree was then calculated after omitting the first b25\% trees as burn-in. 


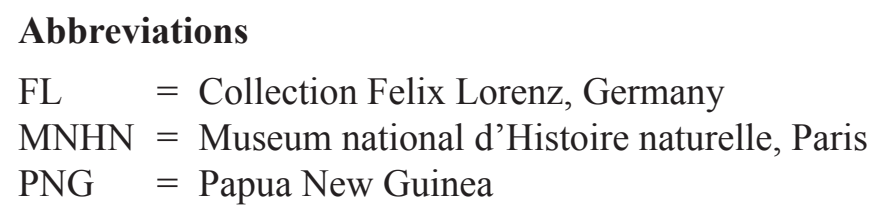

\section{Results}

Five specimens of Conus hughmorrisoni sp. nov. were successfully sequenced for a $658 \mathrm{bp}$ fragment of the COI gene. The K2P genetic distances among the five specimens are very low $(0.2-0.3 \%)$ and correspond to genetic distances generally considered as intraspecific distances in cone snails; conversely all the genetic distances with other known cone snail species are large $(>10 \%)$ and correspond to genetic distances generally considered as interspecific distances in cone snails (e.g. Duda et al. 2008; Puillandre et al. 2011). The preliminary analysis using the NJ method suggests that the new species belongs to the Splinoconus clade, as defined in Puillandre et al. (2014). Consequently, the dataset was then limited to species belonging to this clade, together with additional species from closely related clades (Leporiconus, Floraconus) and more distantly related cone snails. In the resulting tree (Fig. 1), the five specimens of Conus hughmorrisoni sp. nov. are grouped in a highly supported clade (Posterior Probability $=1$ ). The species clusters in the Splinoconus clade (Posterior Probability $=1$ ). The new species is described below.

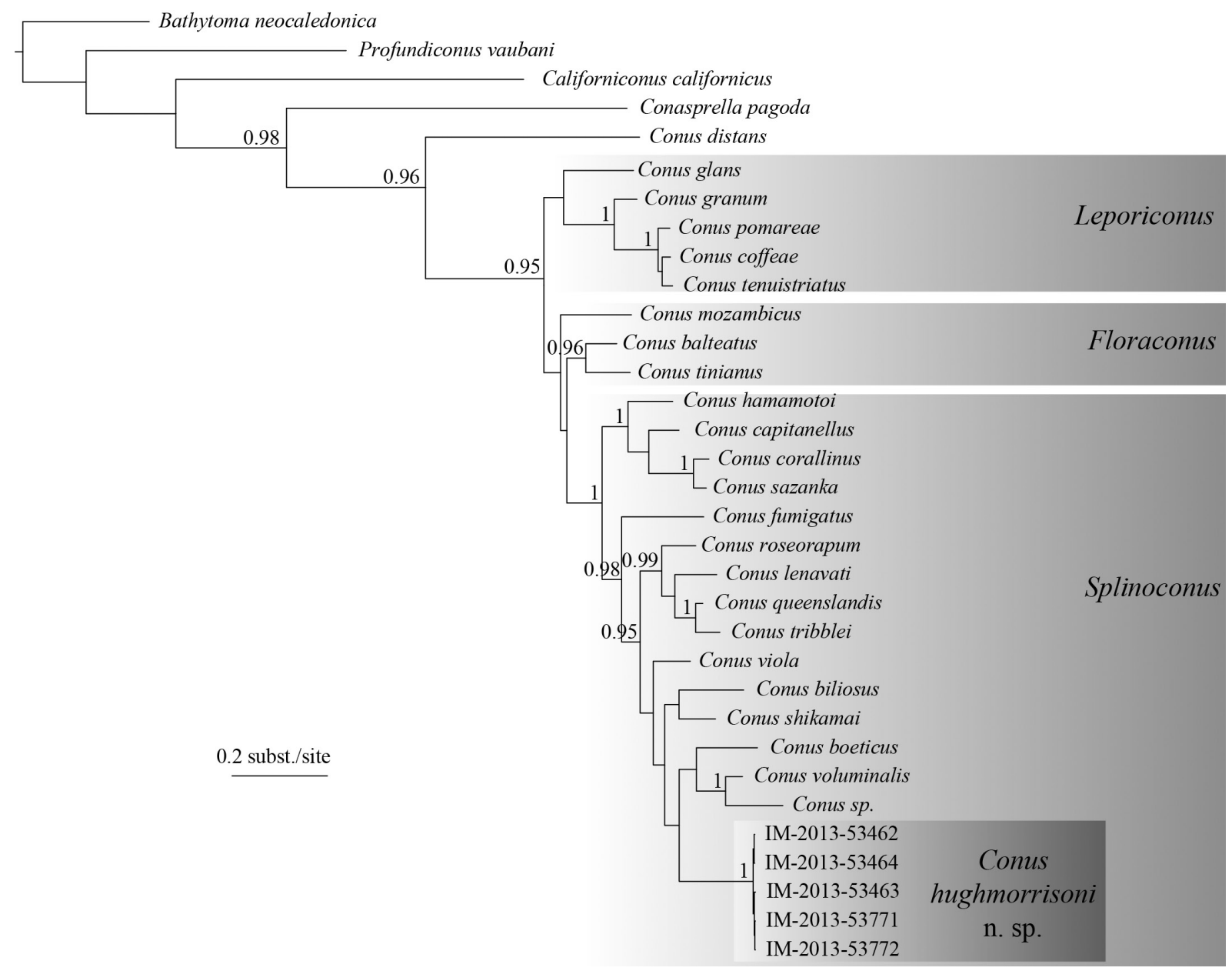

Fig. 1. Bayesian phylogenetic tree obtained with the COI gene. Posterior Probabilities $(>0.9)$ are shown above nodes). 


\author{
Class Gastropoda Cuvier, 1795 \\ Subclass Caenogastropoda Cox, 1960 \\ Order Neogastropoda Wenz, 1938 \\ Superfamily Conoidea Fleming, 1822 \\ Family Conidae Fleming, 1822 \\ Genus Conus Linnaeus, 1758
}

Conus (Splinoconus) hughmorrisoni sp. nov. urn:lsid:zoobank.org:act:4105F23A-B87D-4D62-842A-476B9E889C24

Table 1; Figs 2-4

\title{
Etymology
}

This new species is named in honour of Hugh Morrison from Perth, Western Australia. He is a well known malacologist, shell dealer and pioneer scuba diver. He led the team of divers on board the MV $P N G$ Explorer during the Kavieng Lagoon Biodiversity Survey. He is among the leading experts in Australian shells, and a dear friend of the first author.

\section{Type material examined}

Holotype and paratypes 1-5 are deposited in the MNHN.

\section{Holotype}

PAPUA NEW GUINEA: MNHN-IM-2013-53462, 20.4 mm, New Ireland, Kavieng Lagoon, E side of Wadei Island, $02^{\circ} 40.3^{\prime} \mathrm{S}, 150^{\circ} 39.1^{\prime} \mathrm{E}, 9-11 \mathrm{~m}$ deep (station KR70), Fig. 2A, BOLD ID CONO1794-15, GenBank accession number (COI sequence) KR070759.

\section{Paratypes}

PAPUA NEW GUINEA: paratype 1, MNHN-IM-2013-53771, 13.25 mm, New Ireland, Kavieng Lagoon, NW point of Ungan Island, $02^{\circ} 38.8^{\prime} \mathrm{S}, 150^{\circ} 39.7^{\prime} \mathrm{E}$, 3-12 m deep (station KR80), Fig. 2BC, BOLD ID CONO1793-15, GenBank accession number (COI sequence): KR070760; paratype 2, MNHN-IM-2013-53463, 12.55 mm, New Ireland, Kavieng Lagoon, E side of Wadei Island, 02 40.3 'S, 150³9.1'E, 9-11 m deep (station KR70), Figs 2D, 3A-B, BOLD ID CONO1795-15, GenBank accession number (COI sequence) KR070758; paratype 3, MNHN-IM-2013-53464, $16.5 \mathrm{~mm}$, New Ireland, Kavieng Lagoon, E side of Wadei Island, 02 ${ }^{\circ} 40.3^{\prime}$ 'S, $150^{\circ} 39.1^{\prime}$ E, 9-11 m deep (station KR70), Figs 2E, 3C-F, BOLD ID CONO1796-15, GenBank accession number (COI sequence) KR070757; paratype 4, MNHN-IM-2013-53772, $10.8 \mathrm{~mm}$, New Ireland, Kavieng Lagoon, NW point of Ungan Island, $02^{\circ} 38.8^{\prime} \mathrm{S}, 150^{\circ} 39.7^{\prime} \mathrm{E}, 3-12 \mathrm{~m}$ deep (station KR80), Fig. 2F-G, BOLD ID CONO179215, GenBank accession number (COI sequence) KR070761; paratype 5, MNHN-IM-2000-27955, $14.15 \mathrm{~mm}$, New Ireland, Kavieng Lagoon, NW point of Ungan Island, $02^{\circ} 38.8^{\prime} \mathrm{S}, 150^{\circ} 39.7^{\prime} \mathrm{E}, 3-12 \mathrm{~m}$ deep (station KR70), Fig. 2H; paratype 6, 21.6 mm, Nusaum Is., New Ireland, FL, Fig. 4A; paratype 7, 19.0 mm, Ungan Is., New Ireland, FL, Fig. 4B; paratype 8, $19.1 \mathrm{~mm}$, Ungan Is., New Ireland, FL, Fig. 4C; paratype 9, $19.6 \mathrm{~mm}$, Wadei Is., New Ireland, FL, Fig. 4D; paratype 10, $18.3 \mathrm{~mm}$, Nusaum Is., New Ireland, FL, Fig. 4E; paratype 11, 18.1 mm, Nusaum Is., New Ireland, Coll. Hugh Morrison, Fig. 4F.

\section{Type locality}

Papua New Guinea, New Ireland, Kavieng Lagoon, E side of Wadei Island, $02^{\circ} 40.3$ 'S, $150^{\circ} 39.1^{\prime}$ E, 9-11 m deep (station KR70).

\section{Description}

The shell of the holotype is rather small and lightweight. The last whorl is moderately broad and conical. The aperture is equally narrow throughout. The spire is pointed, acutely stepped, the outline very slightly 


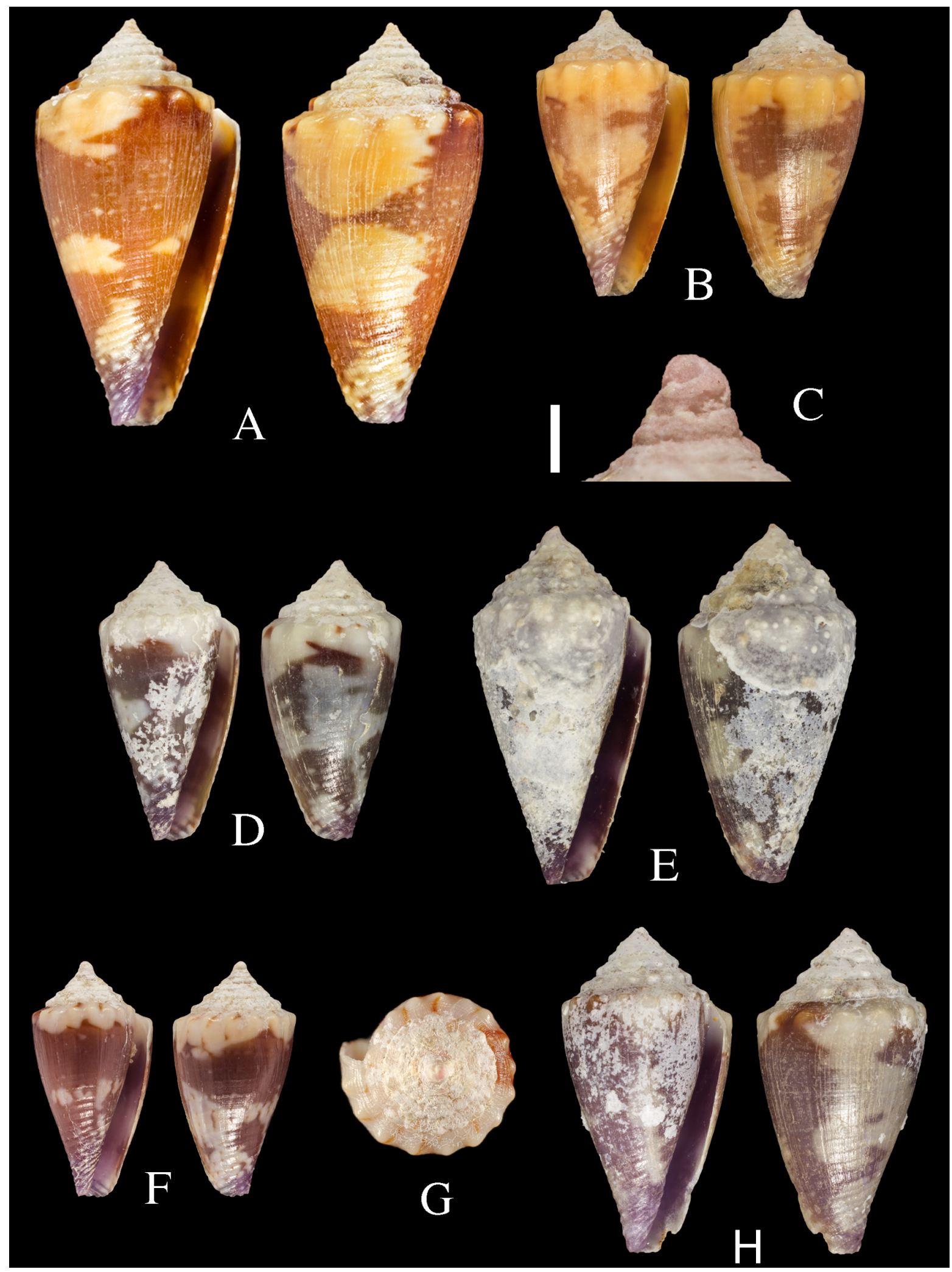

Fig. 2. Conus hughmorrisoni sp. nov. A. Holotype, $20.4 \mathrm{~mm}$. B-C. Paratype 1, $13.25 \mathrm{~mm}$. B. Teleoconch. C. Protoconch (scale bar $=0.5 \mathrm{~mm}$ ). D. Paratype 2, $12.55 \mathrm{~mm}$. E. Paratype 3, $16.5 \mathrm{~mm}$. F-G. Paratype 4, $10.8 \mathrm{~mm}$. F. Teleoconch. G. Top view. H. Paratype 5, $14.15 \mathrm{~mm}$. All pictures by Manuel Caballer Gutierrez (credits project E-Recolnat, MNHN). 


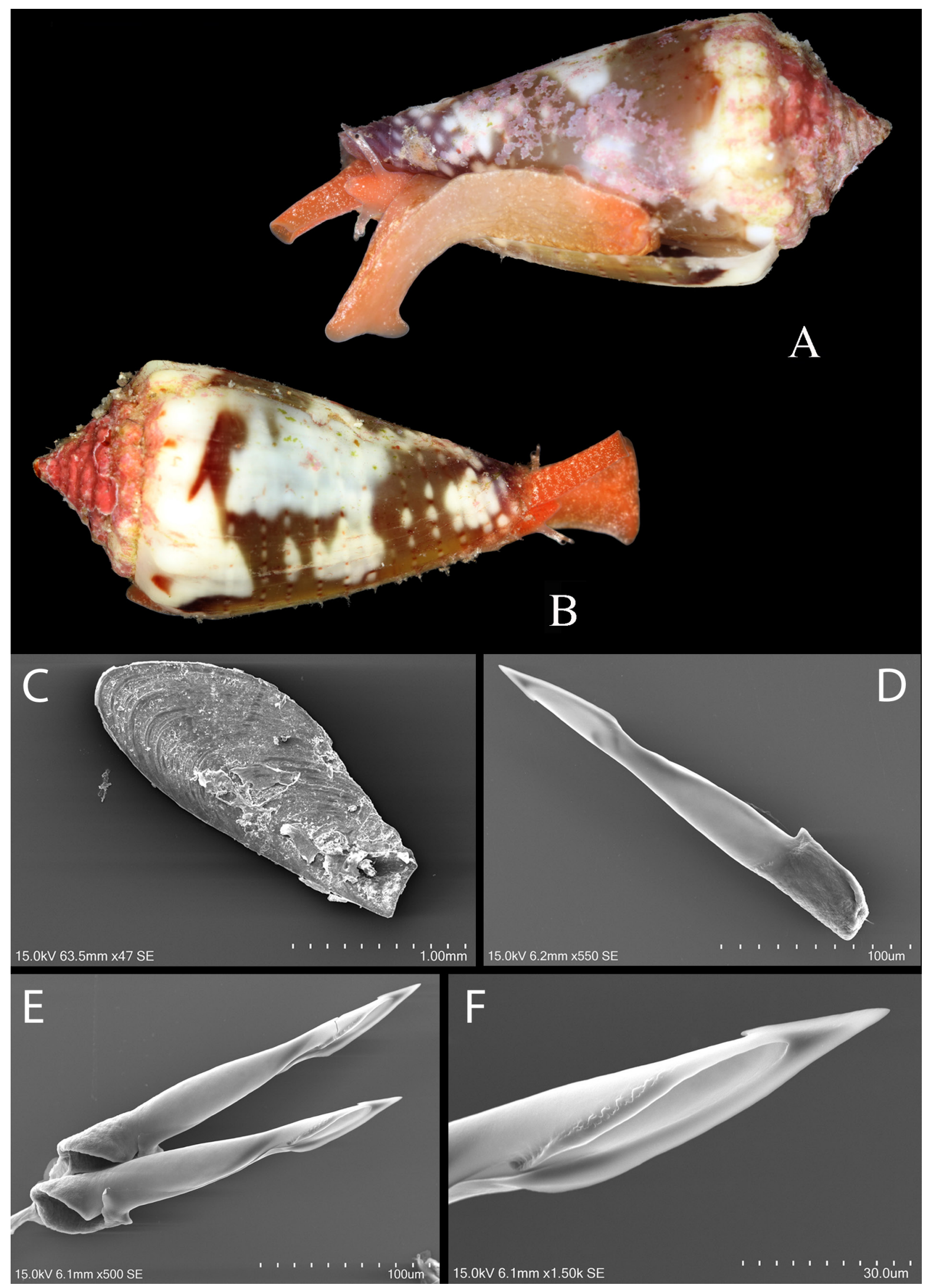

Fig. 3. Conus hughmorrisoni sp. nov. A-B. Paratype 2, $12.55 \mathrm{~mm}$. C. Operculum of paratype 5. D-F. Radula of paratype 3 . 


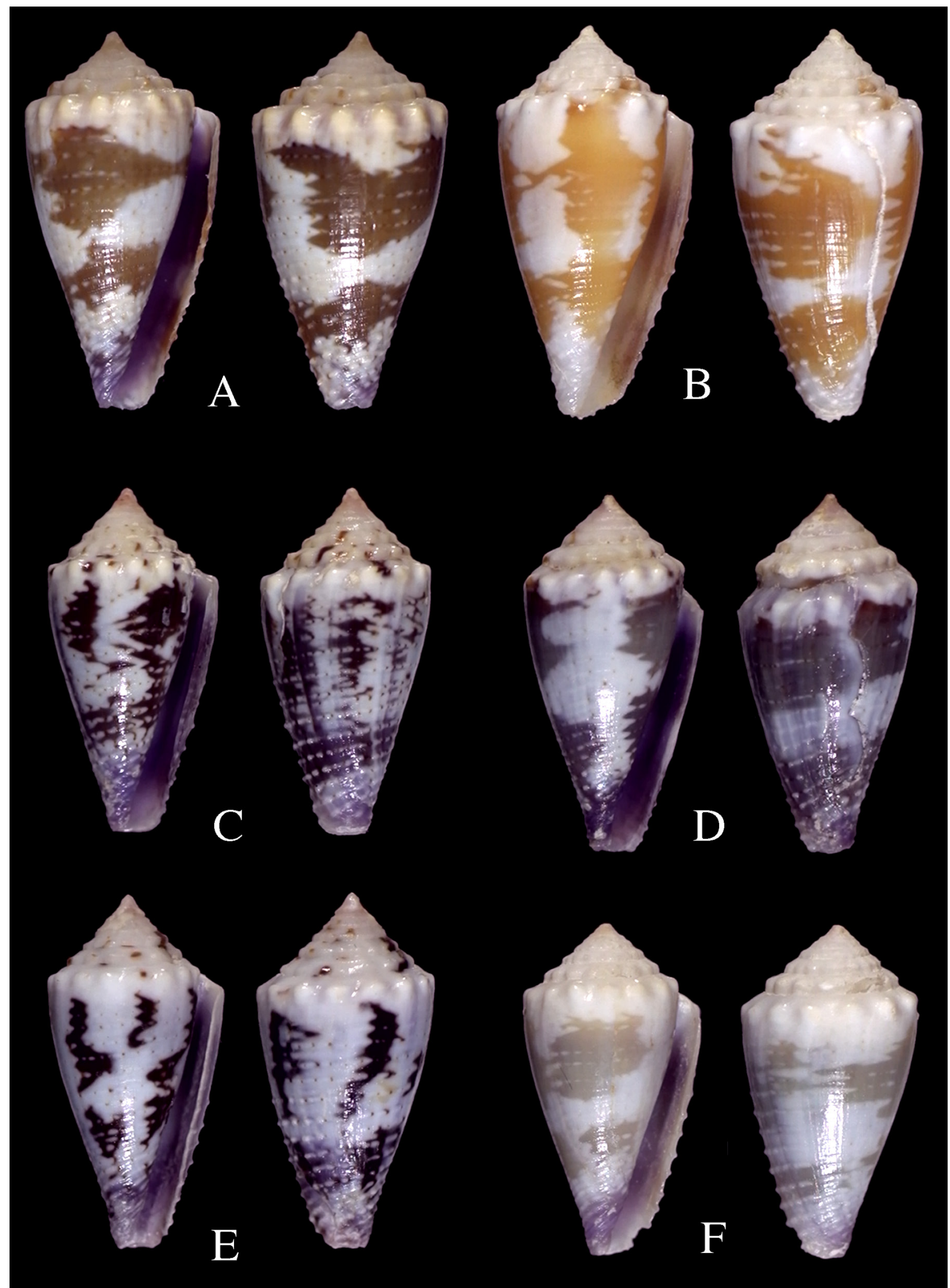

Fig. 4. Conus hughmorrisoni sp. nov. A. Paratype 6, $20.8 \mathrm{~mm}$. B. Paratype 7, $21.6 \mathrm{~mm}$. C. Paratype 8, $19.0 \mathrm{~mm}$. D. Paratype 9, $19.1 \mathrm{~mm}$. E. Paratype 10, $19.6 \mathrm{~mm}$. F. Paratype 11, $18.3 \mathrm{~mm}$. 
concave. The suture is narrow and shallow. The protoconch is smooth, bulbous, of about 2 whorls, measuring about $0.55 \mathrm{~mm}$ in width. It is missing or strongly corroded in all specimens studied (Fig. 2C). The first two postnuclear whorls have no spiral grooves, and their shoulders are shallow and without discernible tubercles. There are three shallow incised striae on the postnuclear sutural ramps, and two to three broader, less distinct striae along the angle of the shoulder and below on the adapical end of the last whorl. The last adult whorl and the preceeding whorl show 15-17 prominent tubercles each (Fig. 2G); their interstices are deeply indented, also below the shoulder, dorsally on the last adult whorl, forming an undulating outline. The number of tubercles increases by one or two in the preceeding earlier whorls, gradually weakening, finally disappearing towards the protoconch. The shell seems glossy and smooth in the half below the spire, but there are regularly spaced, shallow, axially striate spiral grooves between spiral ribbons on its entire surface. These are enhanced by intermittent tubercles which gradually become more prominent and denser towards the abapical end, and directly above the lip. The anal notch is rounded and rather shallow.

The protoconch is pale yellow. The ground colour of the teleoconch is white, with purple on parts of the last whorl. The abapical end is stained with darker purple. The spire is white with occasionaly discrete brown axial lines. The last adult whorl shows irregular brown patches above a pale purple mid-dorsal area without darker pattern; these patches can eventually be connected to form an irregular spiral band. There are numerous, evenly spaced narrow spiral rows of white and brown dots. They appear as rows of white spots within the darker blotches and as discrete red-brown spots in the paler, unblotched areas. The tubercles on the spiral ribbons are white, which is especially obvious in the darker stained abapical end. The interior of the shell is purplish brown.

The paratypes agree with the holotype in all morphological aspects and show basically no variation in shape or the development of the spiral tubercles. In some specimens, the spiral grooves are less developed adapically. The coloration, however, varies considerably: in some specimens, the last adult whorl is rather rich purple and the darker stain of the abapical end is less obvious. The spire is generally white; darker dashes and lines are always discrete. The color of the darker dorsal blotches varies from orange to black. In most shells it is purplish brown, green in one specimen. The spiral rows of white and brown dots are reduced in the paler specimens. The darker blotches above the paler mid-dorsal zone can be fused to a compact dark band with irregular outline; in other specimens there are irregular axial flames in which the borders seem fringed by the white component of the axial lines.

The periostracum is reddish brown and thin. The animal has a brown foot with discrete yellow dashes, the crawling surface is pale brown (Fig. 3A-B). The edge of the transparent orange siphon is framed with black. The operculum is illustrated on Fig. 3C. The radular tooth is of the vermivorous kind, rather slender, and of small relative size $(\mathrm{L} / \mathrm{TL}=72)(\mathrm{Fig} .3 \mathrm{C}-\mathrm{F})$. The anterior portion is much shorter than the posterior section (TL/APL $=2.7-2.8$ ). Waist evident. Apical barb present, opposing a rounded blade which covers most of the anterior portion of the tooth $(100 \mathrm{BL} / \mathrm{APL}=84 \%)$. There are no denticles present in serration. Instead, there are 6-7 raised irregular marginal undulations arranged in one row, ending in a terminating cusp. These structures seem to correspond to precursors of denticles in a primitive serration (protoserration). Base axially elongated, with a small basal spur present, pointing upwards. Measurements of the shells are provided in Table 2 (abbreviations: $\mathrm{L}=$ shell length; $\mathrm{TL}=$ radular tooth length; $\mathrm{APL}=$ anterior portion length; $\mathrm{BL}=$ blade length).

\section{Distribution and habitat}

Conus hughmorrisoni sp. nov. is so far known only from a small area between Kavieng and New Hannover Island to the west of New Ireland, Papua New Guinea: east side of Wadei Island, $02^{\circ} 40.3^{\prime} \mathrm{S}$, $150^{\circ} 39.1^{\prime} \mathrm{E}$ (Station KR70), at 9-11 m, on sand and rubble; NW point of Ungan Island, $02^{\circ} 38.8^{\prime} \mathrm{S}$, $150^{\circ} 39.7^{\prime} \mathrm{E}$ (Station KR80), at 3-12 m, on flat sand and rubble slope with larger corals; S side of Nusaum Island, $02^{\circ} 38.381^{\prime} \mathrm{S}, 150^{\circ} 38.436$ ' $\mathrm{E}$, at 5-24 m, active coral reef 8-15 m, coarse rubble slope 
Table 2. Measurements (in mm) of shells of Conus hughmorrisoni sp. nov., Conus exiguus Lamarck, 1810 (taken from Röckel et al. 1995) and Conus hanshassi (Lorenz \& Barbier, 2012). L = shell length; $\mathrm{MD}=$ maximum diameter; $\mathrm{AH}=$ aperture height; $\mathrm{HMD}=$ height of maximum diameter; $\mathrm{RD}=$ relative diameter of last whorl (MD/AH); PMD = position of maximum diameter of last whorl (HMD/AH); $\mathrm{RSH}=$ relative spire height $((\mathrm{L}-\mathrm{AH}) / \mathrm{L})$.

\begin{tabular}{|c|c|c|c|c|c|c|c|}
\hline & $\mathbf{L}$ & MD & AH & HMD & RD & PMD & RSH \\
\hline C. hughmorrisoni sp. nov. MNHN-IM-2013-53462 (Holotype) & 20.4 & 10.2 & 16.4 & 14.8 & 0.62 & 0.90 & 0.20 \\
\hline C. hughmorrisoni sp. nov. MNHN-IM-2013-53771 (Paratype 1) & 13.3 & 7.2 & 10.6 & 9.9 & 0.68 & 0.93 & 0.21 \\
\hline C. hughmorrisoni sp. nov. MNHN-IM-2013-53463 (Paratype 2) & 12.6 & 6.4 & 10 & 8.7 & 0.64 & 0.87 & 0.21 \\
\hline C. hughmorrisoni sp. nov. MNHN-IM-2013-53464 (Paratype 3) & 16.5 & 8.3 & 12.9 & 11.4 & 0.64 & 0.88 & 0.22 \\
\hline C. hughmorrisoni sp. nov. MNHN-IM-2013-53772 (Paratype 4) & 10.8 & 5.7 & 8.7 & 7.6 & 0.65 & 0.87 & 0.19 \\
\hline C. hughmorrisoni sp. nov. MNHN-IM-2000-27955 (Paratype 5) & 14.2 & 7.4 & 12 & 10.6 & 0.62 & 0.88 & 0.16 \\
\hline Mean values for C. hughmorrisoni & & & & & 0.65 & 0.89 & 0.20 \\
\hline C. exiguus Lamarck, 1810 & $16-54$ & & & & $0.57-0.67$ & $0.83-0.95$ & $0.09-0.20$ \\
\hline $\begin{array}{l}\text { C. hanshassi (Lorenz \& Barbier, 2012) MNHN-IM-2000-24814 } \\
\text { (Holotype) }\end{array}$ & 23.4 & 10.9 & 17.4 & 15.4 & 0.63 & 0.89 & 0.26 \\
\hline
\end{tabular}

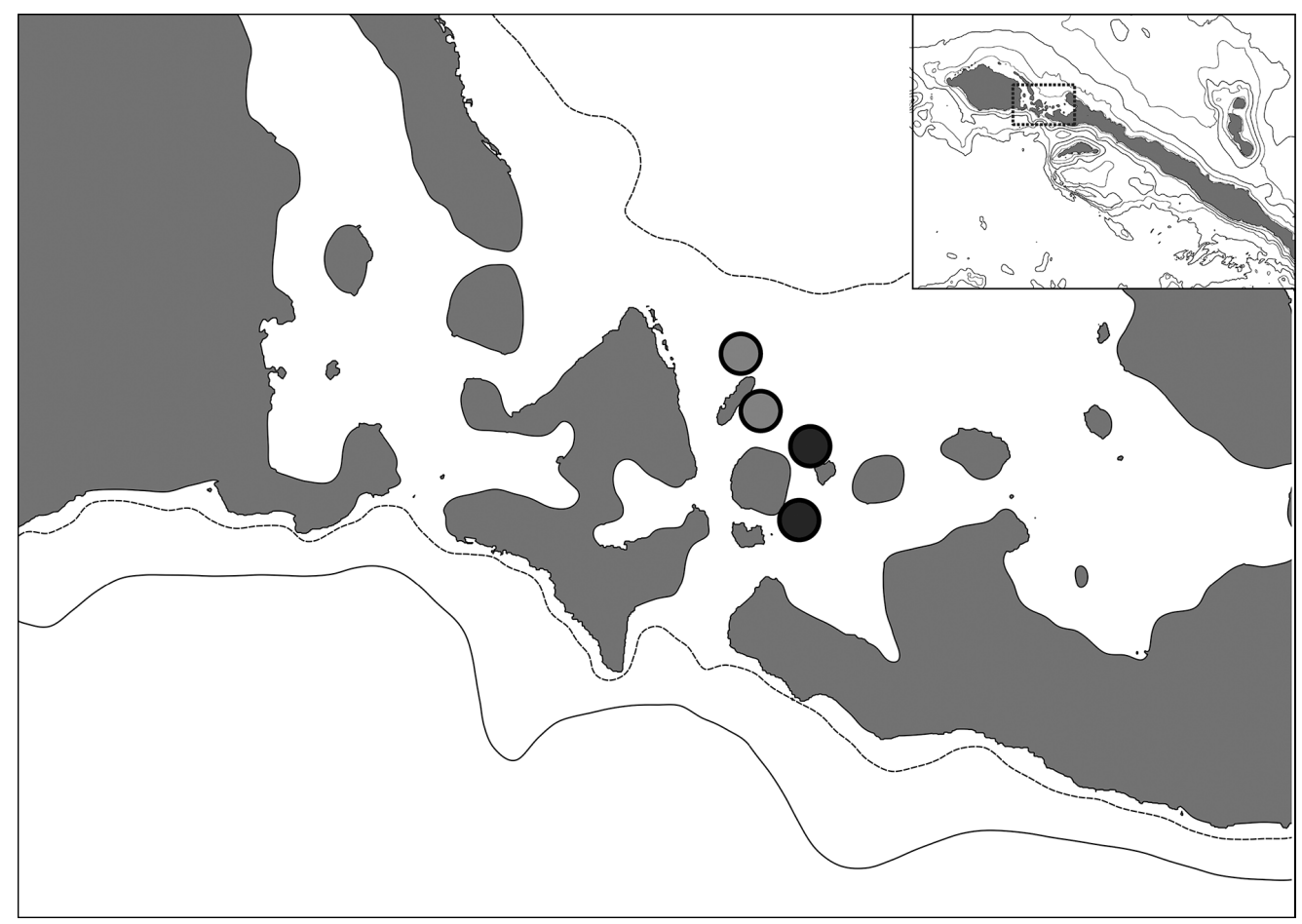

Fig. 5. Map of the Kavieng Region showing the different sampling sites. Black circles: stations with sequenced material; grey circles: stations with other material. 
to gently sloping bottom at $21 \mathrm{~m}$; NW side of Ral Island, $02^{\circ} 36.373$ 'S, $150^{\circ} 38.518^{\prime} \mathrm{E}$, at 4-25 m, slope with coral conglomerate (Fig. 5). Further specimens have been collected in a similar habitat and depth in the vicinity of the islands of Wadei, Ungan and Nusaum.

\section{Remarks}

There are two species of Conidae which should be compared to Conus hughmorrisoni sp. nov.:

Conus (Phasmoconus) exiguus Lamarck, 1810, a highly variable species known only from New Caledonia (Fig. 6A-D). Some of its formae can be similar to C. hughmorrisoni sp. nov. in shape, the tuberculate spire, and by having rows of spiral tubercles. Also, the general color pattern can be quite similar. However, the number of tubercles on the shoulder differs. In C. exiguus and its variations (e.g. the smaller form Conus cabritii Bernardi, 1858), there are 12 to 14 tubercles associated with the last adult whorl, in C. hughmorrisoni sp. nov. there are 15 to 17 . The suture of $C$. exiguus is deeper and the incised sutural striae are more distinct, especially on the early postnuclear whorls. In C. exiguus, the pattern of the last adult whorl is continued on the spire, which hence is often dark blotched. The spire of $C$. hughmorrisoni sp. nov. is usually untinted or shows only discrete spots or lines. The darker patches of C. hughmorrisoni sp. nov. are crossed by the narrow spiral bands of white and dark brown intermittent spots that can be replaced, in some cases, by rows of irregular white dashes. The resulting effect caused by this banding, minute white specks within the darker blotches, and fine brown spots in the paler areas of the dorsum, give the pattern of C. hughmorrisoni sp. nov. a more delicate look.

Conus (Strategoconus) hanshassi (Lorenz \& Barbier, 2012), from Siargao Island in the Philipines, is so far known from only three specimens (Fig. 6E-F). It is somewhat narrower, with a taller spire. Like in C. exiguus, the number of tubercles (12-13) along the shoulder of the last adult whorl is lower than in $C$. hughmorrisoni sp. nov. The color pattern is compact, sparser and extends onto the spire in $C$. hanshassi, in which the narrow spiral bands of white and darker spots of $C$. hughmorrisoni sp. nov. are replaced by numerous fine brown spots arranged in spiral lines across the last adult whorl. As a consequence, the darker blotches of $C$. hanshassi do not show white specks as in C. hughmorrisoni sp. nov.

The ratios, based on measurements of the shells (Table 2), do not show any differences between C. hughmorrisoni sp. nov., C. exiguus and C. hanshassi, except for the RSH ratio of C. hanshassi, which is slighlty higher than for both the other species, albeit based on only one specimen of $C$. hanshassi.

\section{Discussion}

The species Conus hughmorrisoni sp. nov. is molecularly different from all the species of Conus available in GenBank, and in this regard molecular data does not contradict the fact that it corresponds to a new species. However, the species morphologically resembles two other cone snails: Conus exiguus and Conus hanshassi. The radula is known for one of them, Conus exiguus (Tucker \& Tenorio 2009); it suggests that $C$. exiguus and C. hughmorrisoni sp. nov. are related, but different species (M. Tenorio pers. com.). The tooth of $C$. exiguus is broader than that of $C$. hughmorrisoni sp. nov., and does not show with clarity (under the optical microscope) any protoserration. The base of the tooth of $C$. exiguus is more rounded than in C. hughmorrisoni sp. nov. in which it is axially elongated. Concerning Conus hanshassi, the radula is unknown but M. Tenorio (pers. com.) considers that it could be a Rolaniconus Tucker \& Tenorio, 2009, a genus-level taxon synonymized with Strategoconus da Motta, 1991 by Puillandre et al. (2015). Although it remains to be confirmed by a molecular analysis, both the characters of the shell (for C. exiguus and C. hanshassi) and of the radular tooth (for C. exiguus) suggest that $C$. hughmorrisoni sp. nov., C. exiguus and C. hanshassi are three different species. 


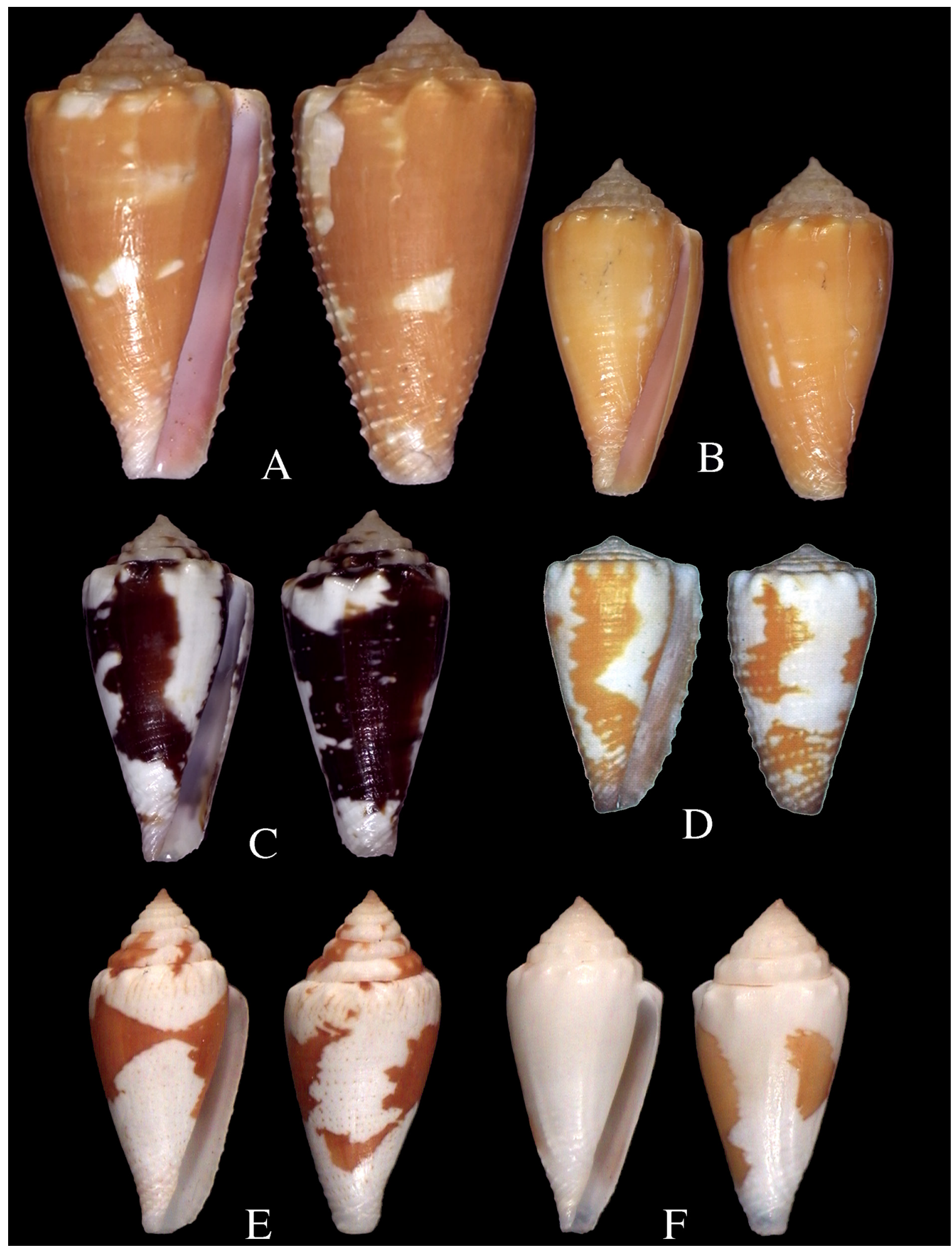

Fig. 6. A. Conus exiguus var. optimus Sowerby, 1913, $35.3 \mathrm{~mm}$. Point Parme, New Caledonia. FL. B. Conus exiguus var. bougei Sowerby, 1907, $20.3 \mathrm{~mm}$. Poum, N. New Caledonia. FL. C. Conus exiguus var. cabritii Bernardi, 1858, $22.0 \mathrm{~mm}$. Northern New Caledonia. FL. D. Conus sp. cf. exiguus, $18.0 \mathrm{~mm}$. Apia, Western Samoa. From Röckel et al. (1995), pl. 72, figs 14-15. E-F. Conus hanshassi (Lorenz \& Barbier, 2012). E. 23.4 mm. Siargao Is., Philippines. Holotype, MNHN-IM-2000-24814. F. 22.9 mm. Siargao Is., Philippines. Paratype 1, FL. 
Geographically, C. hughmorrisoni sp. nov. connects the distribution areas of C. hanshassi and C. exiguus. These three species seem to represent close allies along a line that marks the distribution of several other species-complexes of the famliy (e.g. australis, coccineus, corallinus, monachus, mucronatus, proximus, and their closer relatives). The continuation of this line eastwards is suggested by an undescribed species illustrated in Röckel et al. (1995, pl. 72, figs 14-15) from Western Samoa. This shell has a rather flat spire with few, prominent tubercles and a heavily tuberculate last adult whorl. Its color pattern resembles that of $C$. exiguus. We have little doubt that additional related species will be discovered along the line between the Philippines, Papua New Guinea, New Caledonia and Samoa. The paucispiral protoconch of C. hughmorrisoni sp. nov. and C. hanshassi suggests intracapsular development or at least an abbreviated planctonic stage that limits the dispersal of larvae over greater distances (Jablonski \& Lutz 1980). The same seems to be true for $C$. exiguus from New Caledonia, whose radiation into numerous local and bathymetric forms (and eventually sibling species, see Röckel et al. 1995) may be the result of such isolation based on limited dispersal.

\section{Acknowledgements}

Part of the material was collected during the Kavieng Lagoon Biodiversity Survey in Papua New Guinea (June 2014; Principal Investigators: Philippe Bouchet, Jeff Kinch), as part of the Our Planet Reviewed expeditions organized jointly by Muséum national d'Histoire naturelle (MNHN), Pro-Natura International (PNI) and Institut de Recherche pour le Développement (IRD), with support from Papua New Guinea's National Fisheries Authority. The organizers acknowledge supporting funding from the Total Foundation, the Laboratoire d'Excellence Diversités Biologiques et Culturelles (LabEx BCDiv, ANR-10-LABX-0003-BCDiv), the Programme Investissement d'Avenir (ANR-11-IDEX-0004-02), the Fonds Pacifique, and CNRS' Institut Ecologie et Environnement (INEE). The expedition was endorsed by the New Ireland Provincial Administration and operated under a Memorandum of Understanding with the University of Papua New Guinea (UPNG). This project was partly supported by the Service de Systématique Moléculaire (UMS 2700 CNRS-MNHN) and by the project CONOTAX, funded by the French ANR (grant number ANR-13-JSV7-0013-01). The authors also thank Virginie Héros, Barbara Buge, Julien Brisset, Manuel Caballer Gutierrez, Laetitia Aznar-Cormano and Gilberto Marani for their help in curating the specimens, Alexander Fedosov and Manolo Tenorio for radula preparation and analysis, Dietmar and Ange Amon (Lissenung Island, Kavieng), Dr. Marco Chiapponi (Chiapponi Lorenz Seashell Foundation, Lecco, Italy), Dr. Michael A. Mont (Molluscan Science Foudation, Owings Mills, Maryland, USA), Jean Pierre Barbier, Jana Kratzsch, and Alan J. Kohn and two anonymous referees for their comments on a previous version of the manuscript.

\section{References}

Ahyong S.T. 2014. Paramoguai kavieng, a new genus and species of camptandriid crab from Papua New Guinea (Crustacea: Brachyura). Zootaxa 3856: 578-584. http://dx.doi.org/10.11646/zootaxa.3856.4.6

Bacher S. 2012. Still not enough taxonomists: reply to Joppa et al. Trends in Ecology and Evolution 27 (2): 65-66. http://dx.doi.org/10.1016/j.tree.2011.11.003

Dance S.P. 1986. A History of Shell Collecting. Brill and Backhuys, Leiden.

Duda T.F.Jr., Bolin M.B., MeyerC. \& Kohn A.J. 2008. Hidden diversity in a hyperdiverse gastropod genus: discovery of previously unidentified members of a Conus species complex. Molecular Phylogenetics and Evolution 49 (3): 867-876. http://dx.doi.org/10.1016/j.ympev.2008.08.009

Duda T.F.Jr. \& Kohn A.J. 2005. Species-level phylogeography and evolutionary history of the hyperdiverse marine gastropod genus Conus. Molecular Phylogenetics and Evolution 34 (2): 257-272. http://dx.doi. org/10.1016/j.ympev.2004.09.012 
Dutertre S., Jin A.H., Kaas Q., Jones A., Alewood P.F. \& Lewis R.J. 2013. Deep venomics reveals the mechanism for expanded peptide diversity in cone snail venom. Molecular \& Cellular Proteomics 12: 312-329. http://dx.doi.org/10.1074/mcp.M112.021469

Edgar R.C. 2004. MUSCLE: multiple sequence alignment with high accuracy and high throughput. Nucleic Acids Research 32 (5): 1792-1797. http://dx.doi.org/10.1093/nar/gkh340

Folmer O., Black M., Hoeh W., Lutz R. \& Vrijenhoek R. 1994. DNA primers for amplification of mitochondrial cytochrome c oxidase subunit I from diverse metazoan invertebrates. Molecular Marine Biology and Biotechnology 3 (5): 294-299.

Galindo L.A., Puillandre N., Strong E.E. \& Bouchet P. 2014. Using microwaves to prepare gastropods for DNA barcoding. Molecular Ecology Resources 14 (4): 700-705. http://dx.doi.org/10.1111/1755$\underline{0998.12231}$

Huelsenbeck J.P., Ronquist F. \& Hall B. 2001. MrBayes: Bayesian inference of phylogeny. Bioinformatics 17 (8): 754-755. http://dx.doi.org/10.1093/bioinformatics/17.8.754

Jablonski D. \& Lutz R.A. 1980. Molluscan larval shell morphology-ecological and paleontological applications. In: Rhoads D.C. \& Lutz R.A. (eds) Skeletal Growth of Aquatic Organisms: 323-377. Plenum Press, New York.

Puillandre N., Bouchet P., Duda T.F.Jr., Kauferstein S., Kohn A.J., Olivera B.M. \& Meyer C. 2014. Molecular phylogeny and evolution of the cone snails (Gastropoda, Conoidea). Molecular Phylogenetics and Evolution 78: 290-303. http://dx.doi.org/10.1016/j.ympev.2014.05.023

Puillandre N., Duda T.F.Jr., Meyer C.P., Olivera B.M. \& Bouchet P. 2015. One, four or 100 genera? A new classification of the cone snails. Journal of Molluscan Studies 81 (1): 1-23. http://dx.doi. org/10.1093/mollus/eyu055

Puillandre N., Meyer C.P., Bouchet P. \& Olivera B.M. 2011. Genetic divergence and geographical variation in the deep-water Conus orbignyi complex (Mollusca: Conoidea). Zoologica Scripta 40 (4): 350-363. http://dx.doi.org/10.1111/j.1463-6409.2011.00478.x

Rambaut A. \& Drummond A.J. 2007. Tracer v1.4. Available from http://beast.bio.ed.ac.uk/Tracer [accessed 15 Jul. 2015].

Röckel D., Korn W. \& Kohn A.J. 1995. Manual of the Living Conidae. Vol. I. Indo-Pacific. Christa Hemmen Verlag, Wiesbaden.

Tamura K., Peterson D., Peterson N., Stecher G., Nei M. \& Kumar S. 2011. MEGA5: Molecular Evolutionary Genetics Analysis using Maximum Likelihood, Evolutionary Distance, and Maximum Parsimony Methods. Molecular Biology and Evolution 28 (10): 2731-2739. http://dx.doi.org/10.1093/ $\underline{\text { molbev/msr121 }}$

Tucker J.K. \& Tenorio M.J. 2009. Systematic Classification of Recent and Fossil Conoidean Gastropods. Conchbooks, Hackenheim.

Violette A., Biass D., Dutertre S., Koua D., Piquemal D., Pierrat F., Stöcklin R. \& Favreau P. 2012. Large-scale discovery of conopeptides and conoproteins in the injectable venom of a fish-hunting cone snail using a combined proteomic and transcriptomic approach. Journal of Proteomics 75 (17): 52155225. http://dx.doi.org/10.1016/j.jprot.2012.06.001

WoRMS Editorial Board. 2014. World Register of Marine Species. Available from http://www. marinespecies.org at VLIZ [accessed 1 Oct. 2014]. 
Manuscript received: 10 October 2014

Manuscript accepted: 9 May 2015

Published on: 16 July 2015

Topic editor: Rudy Jocqué

Section editor: Kurt Jordaens

Desk editor: Charlotte Thionois

Printed versions of all papers are also deposited in the libraries of the institutes that are members of the EJT consortium: Muséum national d'Histoire naturelle, Paris, France; Botanic Garden Meise, Belgium; Royal Museum for Central Africa, Tervuren, Belgium; Natural History Museum, London, United Kingdom; Royal Belgian Institute of Natural Sciences, Brussels, Belgium; Natural History Museum of Denmark, Copenhagen, Denmark. 